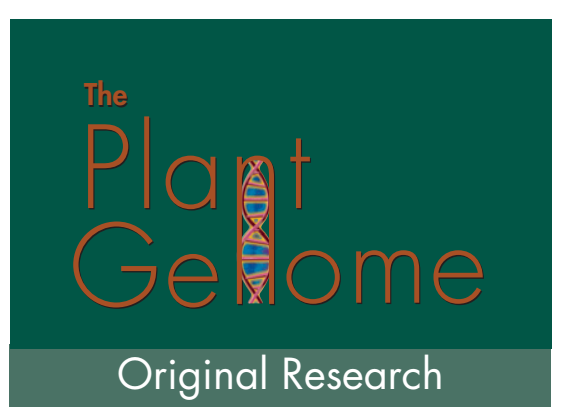

\title{
Genomic Origins of Potato Polyploids: GBSSI Gene Sequencing Data
}

\author{
David M. Spooner, Flor Rodríguez, Zsolt Polgár, \\ Harvey E. Ballard, Jr., and Shelley H. Jansky
}

D.M. Spooner, F. Rodríguez, and S.H. Jansky, USDA-ARS, Dep. of Horticulture, University of Wisconsin, 1575 Linden Dr., Madison, WI 53706-1590; Z. Polgár, University of Pannonia, Center of Agricultural Sciences, Potato Research Centre, 8360 Keszthely, Deak F. u. 16., Hungary; H.E. Ballard, Jr., Dep. of Environmental and Plant Biology, Ohio University, 317 Porter Hall, Athens, OH 45701-2979. Received 11 Sept. 2007. *Corresponding author (david.spooner@ars.usda.gov).

\begin{abstract}
Chromosome pairing relationships within cultivated potato (Solanum tuberosum) and its wild tuber-bearing relatives (Solanum sect. Petota) have been interpreted by genome formulas, developed in the early 1900s, through techniques of classic meiotic analysis of interspecific hybrids. Here we reexamine potato genome hypotheses with the first phylogenetic analysis of all major genomes of sect. Petota using cloned DNA sequences of the single-copy nuclear gene GBSSI (waxy). Our results provide the first molecular confirmation of allopolyploidy in wild potato. They both support prior hypotheses and identify novel genome origins never before proposed. The data will be useful to help design crossing strategies to incorporate wild species germplasm into cultivated potato.
\end{abstract}

Published in Crop Sci. 48(S1) S27-S36. Published 8 Feb. 2008. doi:10.2135/cropsci2007.09.0504tpg

(C) Crop Science Society of America

677 S. Segoe Rd., Madison, WI 53711 USA
The cultivated potato, Solanum tuberosum, has about 190 wild species tuber-bearing relatives, forming a well-defined phylogenetic group, Solanum sect. Petota (Spooner and Salas, 2006). The wild species represent diverse gene pools that are of great importance in breeding resistant and heterotic genotypes. However, not more than $10 \%$ of them are currently involved in the breeding process (Ross, 1986). A better understanding of their genome relationships would clarify the prospects for introgression of alien genes into potato and will help in planning effective breeding programs.

About $70 \%$ of these wild species are diploid at $2 n=$ $2 x=24$, with the remaining species polyploid, mostly at the tetraploid $(2 n=4 x=48)$ or hexaploid $(2 n=6 x=72)$ levels. These polyploids are valuable sources of genes for disease resistance, stress tolerance, and improved tuber quality in potato. For example, $S$. demissum is a source of late blight (Phytophthora infestans) resistance and has been incorporated into potato cultivars (Plaisted and Hoopes, 1989). Solanum acaule is a source of frost tolerance (Vega et al., 2000), and S. hjertingii is resistant to bruising (Culley et al., 2002). Other Solanum allopolyploids contain genes for resistance to soft rot (Pectobacterium spp.), bacterial ring rot (Clavibacter michiganensis subsp. sepedonicus), potato leafroll virus, potato virus X, and potato virus Y (Jansky, 2000).

Abbreviations: AFLP, amplified fragment length polymorphism; EBN, endosperm balance number; MP, maximum parsimony. 
Moreover, multiple disease resistances have been reported in germplasm containing S. demissum and $S$. stoloniferum (DeJong et al., 2001). An understanding of the biology of these species aids breeders in developing effective strategies to introgress this valuable germplasm into the cultivated potato.

\section{Potato Taxonomy and Plastid DNA Phylogeny}

Recent morphological and molecular results show interspecific relationships sometimes at great variance with the latest comprehensive classification of potato by Hawkes (1990; Table 1). Hawkes (1990) recognized 232 species divided into 21 taxonomic series, but the most recent estimate (Spooner and Salas, 2006) is about 190 species divided into four clades (Fig. 1). At lower taxonomic levels and important to this study, the Mexican hexaploid species S. demissum was shown to be related to the South American tetraploid species $S$. acaule and S. albicans, not to other members of series Demissa (Spooner et al., 1995; Kardolus et al., 1998; Kardolus, 1999; Nakagawa and Hosaka, 2002). Spooner et al. (2004) used these results to classify $S$. acaule, S. albicans, and S. demissum in an informal Acaulia Group, and the other members of series Demissa (S. hougasii, $S$. iopetalum, and S. schenckii) in an informal Iopetala Group. We use the terms Acaulia and Iopetala Groups in the text but show Hawkes's (1990) traditional series classifications in Table 1.

The four-clade phylogeny is based on plastid DNA data (Spooner et al., 1991, 1993; Spooner and Sytsma, 1992; Castillo and Spooner, 1997; Rodríguez and Spooner, 1997; Spooner and Castillo, 1997). These four clades comprise (i) the North and Central American diploid species, exclusive of S. bulbocastanum, S. cardiophyllum, and S. verrucosum; (ii) S. bulbocastanum and S. cardiophyllum, (iii) all examined members of the South American series Piurana and some South American species classified to other series, such as S. andreanum; and (iv) all remaining South American species and the North and Central American polyploid species and S. verrucosum (Fig. 1, Table 1).

\section{Genome Hypotheses in Potato}

Chromosome pairing relationships have been variously interpreted by genome formulas (Marks, 1955; Hawkes, 1958; Irikura, 1976; Ramanna and Hermsen, 1979; Matsubayashi, 1991). These were generated through classic genome analysis developed in the early 20 th century by Kihara (1919) from meiotic interpretations of interspecific hybrids.
Matsubayashi (1991) standardized these diverse genome interpretations as $\mathrm{A}, \mathrm{B}, \mathrm{C}, \mathrm{D}$, and $\mathrm{P}$, with an additional genome (E) for members of related section Etuberosum (Table 2). The cultivated potato, $S$. tuberosum, is an A genome species and is composed of a range of cytotypes from diploid to tetraploid (Spooner et al., 2007b). Its tetraploid cytotype is believed to be autotetraploid. The identity of the genomes in the allopolyploids relative to the diploids has long been the subject of debate and uncertainty. For example, the genomes $\mathrm{C}$ and $\mathrm{D}$ of series Conicibaccata and Demissa had no extant diploid species counterparts.

The present study reexamines genome relationships of potato by phylogenetic analysis of a single-copy gene in potato diploids and polyploids. The advantages and disadvantages of using singlecopy sequences for phylogenetic analysis have been reviewed by Wolfe et al. (1987), Gaut (1998), Doyle and Doyle (1999), Sang (2002), and Small et al. (2004). These include, for example, biparental inheritance. Most plastid DNA phylogenies are uniparental, mostly maternal. In taxa with a history of transfer of plastids from one species to another through hybridization, followed by introgression from the (generally paternal) parent, DNA phylogenies are only of one parent. Second, the lack of concerted evolution is a phenomenon in multiple gene families that can produce and maintain a single or dominant DNA type. Finally, there are high rates of evolution, especially in intronic regions, and the general independent evolution of paralogous sequences tend to make them stable in position and copy number. This latter quality is especially important for groups such as potato, which consist of closely related species.

With careful choice of true homologs (or homeologues), single-copy nuclear markers have been useful in identifying parental contributors to polyploids in cotton (Gossypium L.) (Cronn et al., 1999; Senchina et al., 2003), Clarkia (Ford and Gottlieb, 2002), Oxalis (Emshwiller and Doyle, 2002), Paeonia (Sang and Zhang, 1999), Isoëtes (Hoot et al., 2004), soybean [Glycine max (L.) Merr.] (Doyle et al., 2004), rice (Oryza sativa L.) (Ge et al., 1999), Elymus (Mason-Gamer, 2001, 2004), and the cereal crop Eragrostis tef (Ingram and Doyle, 2003). In addition to actual sequence data, genome-specific DNA sequences can be identified to design probes to amplify DNA in allopolyploids, followed by restriction digests and comparison of additivity of bands to diploid progenitors (Vanichanon et al., 2003).

For our reexamination of genome relationships, we used the single-copy potato GBSSI (GranuleBound Starch Synthase I, or waxy) gene. It comprises 
Table 1. Species and accessions examined with GBSSI sequence data and comparisons to previous studies.

\begin{tabular}{|c|c|c|c|c|c|c|c|c|c|}
\hline $\begin{array}{l}\text { Series of potato clade (Hawkes, } \\
\text { 1990) species, and outgroup }\end{array}$ & $\begin{array}{l}\text { Accessions (no. of } \\
\text { clones sequenced) }^{\dagger}\end{array}$ & Ploidy ${ }^{\ddagger}$ & $\begin{array}{l}\text { GBSSI } \\
\text { clade }\end{array}$ & $\begin{array}{l}\text { Plastid } \\
\text { clade }\end{array}$ & $\begin{array}{l}\text { Series of potato clade (Hawkes, } \\
\text { 1990) species, and outgroup }\end{array}$ & $\begin{array}{l}\text { Accessions (no. of } \\
\text { clones sequenced) }\end{array}$ & Ploidy ${ }^{\ddagger}$ & $\begin{array}{l}\text { GBSSI } \\
\text { clade }\end{array}$ & $\begin{array}{l}\text { Plastid } \\
\text { clade }\end{array}$ \\
\hline \multirow{2}{*}{\multicolumn{5}{|c|}{$\begin{array}{l}\text { Solanum sect. Petota Dumort. } \\
\text { (potato clade) }\end{array}$}} & S. piurae Bitter & \multirow[t]{2}{*}{310997} & \multirow[t]{2}{*}{2} & \multirow[t]{2}{*}{3} & \multirow[t]{2}{*}{3} \\
\hline & & & & & Polyadenia Correll & & & & \\
\hline \multicolumn{5}{|l|}{ Acaulia Juz. } & S. polyadenium Greenm. & \multirow[t]{2}{*}{161728} & \multirow[t]{2}{*}{2} & \multirow[t]{2}{*}{$1+2$} & \multirow[t]{2}{*}{1} \\
\hline S. acaule Bitter & $472735(7)$ & 4 & 4 & 4 & Tuberosa (Rydb.) Hawkes & & & & \\
\hline S. albicans (Ochoa) Ochoa & 230494 (11) & 6 & 4 & 4 & S. andreanum Baker & 320345 & 2 & 3 & 3 \\
\hline \multicolumn{5}{|l|}{ Bulbocastana (Rydb.) Hawkes } & S. avilesii Hawkes and Hiert. & 498091 & 2 & 4 & 4 \\
\hline \multicolumn{5}{|l|}{$\begin{array}{l}\text { S. bulbocastanum Dunal } \\
\text { Conicibaccata Bitter }\end{array}$} & S. berthaultii Hawkes & $\begin{array}{l}498096,498105 \\
545851\end{array}$ & 2 & 4 & 4 \\
\hline S. colombianum Bitter & $498150(8)$ & 4 & 3,4 & 4 & S. bukasovii Juz. & 210042 & 2 & 4 & 4 \\
\hline S. moscopanum Hawkes & $567844(4)$ & 6 & 3,4 & 4 & S. candolleanum P. Berthault & 545972 & 2 & 4 & 4 \\
\hline S. santolallae Vargas & 195168 & 2 & 4 & 4 & S. tuberosum L. Group & \multirow{2}{*}{$265882(10)$} & \multirow{2}{*}{4} & \multirow{2}{*}{4} & \multirow{2}{*}{4} \\
\hline S. violaceimarmoratum Bitter & 473396 & 2 & 4 & 4 & Andigenum & & & & \\
\hline \multicolumn{5}{|l|}{ Cuneoalata Hawkes } & S. tuberosum Group Chilotanum & $245835(6)$ & 4 & 4 & 4 \\
\hline S. infundibuliforme Phil. & 472857 & 2 & 4 & 4 & $\begin{array}{l}\text { S. tuberosum Group } \\
\text { Stenotomum }\end{array}$ & 234011 & 2 & 4 & 4 \\
\hline \multicolumn{5}{|l|}{ Demissa Bukasov } & S. vernei Bitter and Wittm. & 458371 & 2 & 4 & 4 \\
\hline S. demissum Lind. & $545757(10)$ & 6 & 4 & 4 & S. verrucosum Schltdl. & \multirow[t]{2}{*}{545745} & \multirow[t]{2}{*}{2} & \multirow[t]{2}{*}{4} & \multirow[t]{2}{*}{4} \\
\hline S. hougasii Correll & $161174(7)$ & 6 & 3,4 & 4 & Yungasensa Correll & & & & \\
\hline S. iopetalum (Bitter) Hawkes & $275183(9)$ & 6 & 3,4 & 4 & S. tarijense Hawkes ${ }^{\S}$ & \multirow[t]{4}{*}{545922,566799} & \multirow[t]{4}{*}{2} & \multirow[t]{4}{*}{4} & \multirow[t]{4}{*}{4} \\
\hline S. schenckii Bitter & $558457(9)$ & 6 & 3,4 & 4 & Potato outgroups & & & & \\
\hline Lignicaulia Hawkes & & & & & Solanum sects. Lycopersicum and & & & & \\
\hline S. lignicaule Vargas & 473351 & 2 & 4 & 4 & Lycopersicoides (tomato clade) & & & & \\
\hline Longipedicellata Bukasov & & & & & S. pimpinellifolium L. & LA722 & 2 & & \\
\hline \multirow[t]{2}{*}{ S. stoloniferum Schltdl. } & \multirow{3}{*}{$\begin{array}{l}186544(7), 251740(5), \\
255546(7), 497998(3) \\
498050(5), 545713(5)\end{array}$} & 4 & $1+2,4$ & 4 & S. lycopersicum L. & LA1673 & 2 & & \\
\hline & & 4 & l+? 4 & 4 & S. peruvianum L. & LA2744 & 2 & & \\
\hline Megistacroloha Córd and Hawkes & & 4 & $1+L, 4$ & 4 & S. pennellii Correll & LA716 & 2 & & \\
\hline S. raphanifolium Cárd. & 265862 & 2 & 4 & 4 & S. Iycopersicoides Dunal & LA1964 & 2 & & \\
\hline and Hawkes & $20000 \mathrm{~L}$ & 2 & 4 & & $\begin{array}{l}\text { Solanum sect. Etuberosum } \\
\text { (Bukasov and Kameraz) A. Child }\end{array}$ & & & & \\
\hline Pinnatisecta (Rydb.) Hawkes & & & & & S. etuberosum Lindl. & 498311 & 2 & & \\
\hline S. cardiophyllum Lindl. & 595465 & 2 & $1+2$ & 2 & S. palustre Poepp. & 558233 & 2 & & \\
\hline S. ehrenbergii (Bitter) Rydb. & 611097 & 2 & $1+2$ & 1 & The six-digit numbers are U.S. Plant In & troduction numbers. & & & \\
\hline S. jamesii Torr. & 458424 & 2 & $1+2$ & 1 & fPloidy $(2 n=24 ; 4 n=48 ; 6 n=72)$. & & & & \\
\hline $\begin{array}{l}\text { Piurana Hawkes } \\
\text { S. pascoense } 0 \text { c }\end{array}$ & & 2 & & & §Placed in synonymy with S. berthaulti & Spooner et al. (20C & but $\mathrm{m}$ & ntaine & \\
\hline J. pasco & & 2 & 0 & 3 & & & & & \\
\hline
\end{tabular}

$4663 \mathrm{bp}$, has 13 introns, and encodes a 58.2 kilodalton mature protein with 540 amino acids (van der Leij et al., 1991). The phylogenetic utility of GBSSI was first demonstrated by Mason-Gamer and Kellogg (1996) in grasses. Many studies documented GBSSI as a single-copy gene in cereals (e.g., Shure et al., 1983; Clark et al., 1991) and in many dicots (e.g., Dry et al., 1992; Wang et al., 1999), although it is clearly duplicated in other lineages (e.g., Evans et al., 2000). The GBSSI gene was cloned and shown to be single copy in potato (van der Leij et al., 1991).

\section{MATERIALS AND METHODS Species}

Forty potato (sect. Petota) accessions representing 33 ingroup taxa were examined. These represent 13 series of Hawkes (1990), all four plastid DNA clades, all even $(2 x, 4 x, 6 x)$ ploidy levels, and all genomic groups of sect. Petota (Fig. 1, Tables 1,2). With cloned sequences, we examined 144 total DNA sequences. We rooted the phylogenetic tree with S. etuberosum and S. palustre (sect. Etuberosum) based on Spooner et al. (1993). Hosaka (2003) supported S. berthaultii (=S. tarijense, Spooner et al., 2007a) as a maternal genome contributor to the evolution of S. tuberosum 


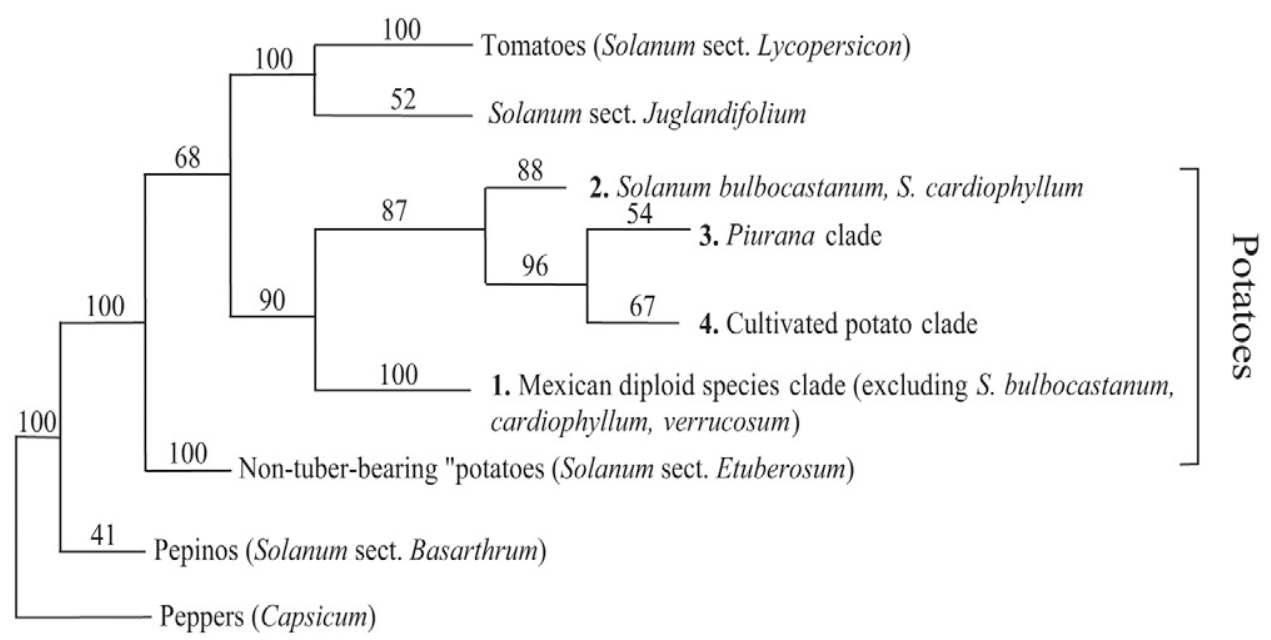

Figure 1. Cladistic relationships of potato, tomato, and outgroups from plastid DNA restriction site data, sensu Spooner and collaborators as described in text, showing the four clades in potato, with bootstrap values above each branch.

Chilotanum Group (Chilean) from Andean populations of this species. We included S. berthaultii, and $S$. bukasovii and S. candolleanum, diploid wild species progenitors of $S$. tuberosum, based on phylogenetic studies of Spooner et al. (2005).

\section{GBSSI Primer Design and Sequencing} DNA sequences were obtained from the first to the eighth exon of GBSSI. All techniques regarding DNA isolation, purification, primer design, cloning, and sequencing follow Peralta and Spooner (2001). A range of 3 to 11 cloned sequences from initial GBSSI amplification products were amplified for the polyploids.

\section{Data Analyses}

Sequence chromatograms were checked for quality and edited by eye in STADEN Package (Staden, 1996). Sequences initially were aligned using ClustalX version 1.81 (Thompson et al., 1997) using a gap opening penalty of 10 , a gap extension penalty of 0.20 , and a delay divergent sequence percentage of $15 \%$. Subsequent minor gap alignments were done by eye. We identified primary sequence types of the polyploids for a given accession and summarized minor differences within these types by using ambiguity codes. We scored gaps by the simple gap scoring method (Simmons and Ochoterena, 2000) using Gap Recoder Web interface (http://maen.huh.harvard.edu:8080/services/ gap_recoder). The aligned DNA file is available as a Supplemental PAUP file. Maximum parsimony (MP) was performed in $\mathrm{PAUP}^{\star} 4.0 \mathrm{~b} 10$ (Swofford, 2002) using DNA sequences and gaps. The most parsimonious trees were found by heuristic searches under Fitch criteria and equal weight for all characters. A rooted strict-consensus tree was obtained and support values were estimated with bootstrap analyses using 300,000 replicates.

\section{Hypothesis Testing}

The phylogenetic placement of the Mexican species S. bulbocastanum and S. cardiophyllum as a separate clade 2, sister to clades 3 and 4 as in the plastid tree (Fig. 1), was examined under MP approaches performing a Templeton test (Templeton, 1983) using only diploid species.

\section{RESULTS}

About $15 \%$ of the DNA sequences appeared to be a result of polymerase chain reaction recombination and were not used for analysis. The aligned DNA

Table 2. Genome designations for Solanum verrucosum (diploid), series Piurana (mostly diploid), and polyploid species in series Acaulia, Demissa, Longipedicellata, and Tuberosa according to the authors listed.

\begin{tabular}{|c|c|c|c|c|c|c|c|}
\hline Author & $\begin{array}{l}\text { S. verrucosum } \\
\text { (diploid) }\end{array}$ & $\begin{array}{l}\text { Ser. Piurana } \\
\quad(2 x)^{a}\end{array}$ & $\begin{array}{l}\text { Ser. Conicibaccata } \\
(2 x, 4 x, 6 x)\end{array}$ & $\begin{array}{l}\text { Ser. Acaulia } \\
(4 x, 6 x)\end{array}$ & $\begin{array}{l}\text { Ser. Demissa } \\
(6 x)\end{array}$ & $\begin{array}{l}\text { Ser. Longipedicellata } \\
(4 x)\end{array}$ & $\begin{array}{l}\text { Ser. Tuberosa } \\
(4 x)\end{array}$ \\
\hline Marks (1955) & A & & & & $A B B^{(1-4)}$ & & \\
\hline Hawkes (1958) & $A_{1}$ & & & $\mathrm{~A}_{2} \mathrm{~A}_{3}$ & $A_{1} A_{4}(B, C, D)$ & $A_{4} B$ & \\
\hline |rikura (1976) & A & & & $A B^{a}$ & $A B^{s} B^{d}$ & $A B^{s}$ & $\mathrm{AA}$ \\
\hline Ramanna and Hermsen (1979) & $A_{1}$ & & & & $A_{1} A_{4} B$ & & \\
\hline Matsubayashi (1991) & $A$ & $\begin{array}{l}\text { Ap (for diploids), AP } \\
\text { (for tetraploids) }\end{array}$ & $\begin{array}{l}\mathrm{A}^{\mathrm{cl}, \mathrm{cl}^{2}}, \mathrm{~A}^{\mathrm{cl}}\left(\mathrm{C}^{(0,1,0)}, \text { no }\right. \\
\text { designation of } 6 x\end{array}$ & $A A^{a}, A A^{a} X^{b}$ & $\operatorname{ADD}^{(b, d, d, s)}$ & $A B$ & $A A^{(s, t)}$ \\
\hline
\end{tabular}


data matrix was 1018 characters long, and gap scores added an additional 93 characters. From these 1111 characters, 159 were parsimony informative; 100 of 159 were nucleotide substitutions and 59 were gap characters. Maximum parsimony analyses produced more than 10,000 trees of 475 steps long with a consistency index of 0.806 and retention index of 0.918 .

We originally direct sequenced all species, both diploid and polyploid. There was a clear difference in sequence between ploidy levels. The diploids provided bands with little allelic polymorphism present only as base pair changes that we could easily score as ambiguity codes. The polyploids showed tremendous polymorphisms that were due to both base pair changes and insertions and deletions; as a result we cloned the polyploids before sequencing them.

A strict consensus tree with overlaid bootstrap values (Fig. 2) shows a topology for the outgroups identical to the plastid DNA topology (Fig. 1). That is, potatoes (Solanum sect. Petota), form a well-supported clade ( $99 \%$ bootstrap support) with tomatoes (Solanum sect. Lycopersicon) sister to them.

The Templeton test was conducted to determine if it was possible to refute the prior hypothesis that S. bulbocastanum and S. cardiophyllum cluster with all South American diploid species and S. verrucosum. Trees constructed by forcing S. bulbocastanum and $S$. cardiophyllum separate from all North and Central diploids and sister to clades 3 and 4 were significantly longer (10 steps longer) than the most parsimonious tree. Therefore, they explain the data statistically worse $(P<0.05)$ than the most parsimonious tree. The GBSSI data are thus incompatible with the hypothesis that S. bulbocastanum and $S$. cardiophyllum cluster apart from the rest of the Mexican and central diploid species as is supported by the plastid data.

Within sect. Petota are three main clades that are similar to the plastid clades (Fig. 1), except that (i) the species of plastid clades 1 and 2 are combined into a single clade (now designated as clade 1+2), (ii) clades $1+2,3$, and 4 form a polytomy, not a defined sister group structure as was defined on the plastid tree, and (iii) clade 4 is divided into two well-supported clades ( $90 \%$ and $87 \%$ bootstrap support).

Figure 3 summarizes the cladistic relationships of the allopolyploids. Members of series Longipedicellata have alleles falling on clade $1+2$, and in clade 4b. Polyploid members of series Conicibaccata have alleles falling on clade 3 and $4 \mathrm{a}$. Members of the Iopetala Group have alleles falling on clades 3, and either $4 \mathrm{a}$ and/or $4 \mathrm{~b}$.

All alleles of $S$. acaule and S. albicans (Acaulia Group) fall on a well-supported clade (81\% bootstrap support) within clade 4 a with some alleles of $S$. demissum (Acaulia Group) and S. schenckii (Iopetala Group). Solanum demissum has alleles falling on clade $4 \mathrm{a}$ and $4 \mathrm{~b}$.

All alleles of the cultivated species S. tuberosum fall entirely within clade $4 \mathrm{~b}$, and its cultivar Groups Andigenum and Chilotanum fall on different subclades of $4 \mathrm{~b}$. Some of these alleles group with their wild species progenitors S. bukasovii and S. candolleanum, in concordance with amplified fragment length polymorphism (AFLP) data (Spooner et al., 2005), while some fall on other subclades. Both tetraploid cultivar groups of $S$. tuberosum (Andigenum, Chilotanum) group with $S$. berthaultii.

\section{DISCUSSION}

We interpret GBSSI to be a valid orthologous phylogenetic marker in all of the species we investigated (i) because of its prior characterization as single copy in cultivated potato (van der Leij et al., 1991), (ii) because of its successful use in the sister clade tomato regarding providing results in concordance with other phylogenies (Peralta and Spooner, 2001), (iii) because of its successful use in our potato study providing phylogenies that are largely concordant with recent plastid phylogenies, and (iv) because recent studies by $\mathrm{Wu}$ et al. (2006) suggest that the Solanaceae and related families have not undergone widespread periods of ancient polyploidization in their history.

Divergent plastid DNA and GBSSI results may highlight important evolutionary events in sect. Petota. The sister relationships of S. bulbocastanum and S. cardiophyllum in a plastid tree (Fig. 1) but not a GBSSI tree (Fig. 2) may signal plastid introgression from species across clades ("plastid or chloroplast capture"). This phenomenon is widely documented in angiosperms (Wendel and Doyle, 1998). Many examples of discordance exist between plastid and nuclear gene trees (Wendel and Doyle, 1998), and the causes of this discordance are not always clear. The significance of the plastid (Fig. 1) and GBSSI (Fig. 2) differences need further exploration with additional nuclear markers, currently in progress.

The allopolyploid origin of members of series Longipedicellata from A and B genomes is unequivocal. It has been suggested by other authors (Table 2), and we here provide the first molecular confirmation of this allopolyploid origin. Because plastid DNA groups all members of series Longipedicellata in clade 4 , the direction of this cross is clearly supported as a maternal A genome parent from clade 4 and a paternal B genome species parent from clade $1+2$. Although no extant species-specific paternal parent is yet clearly supported, its maternal parent is likely $S$. verrucosum 


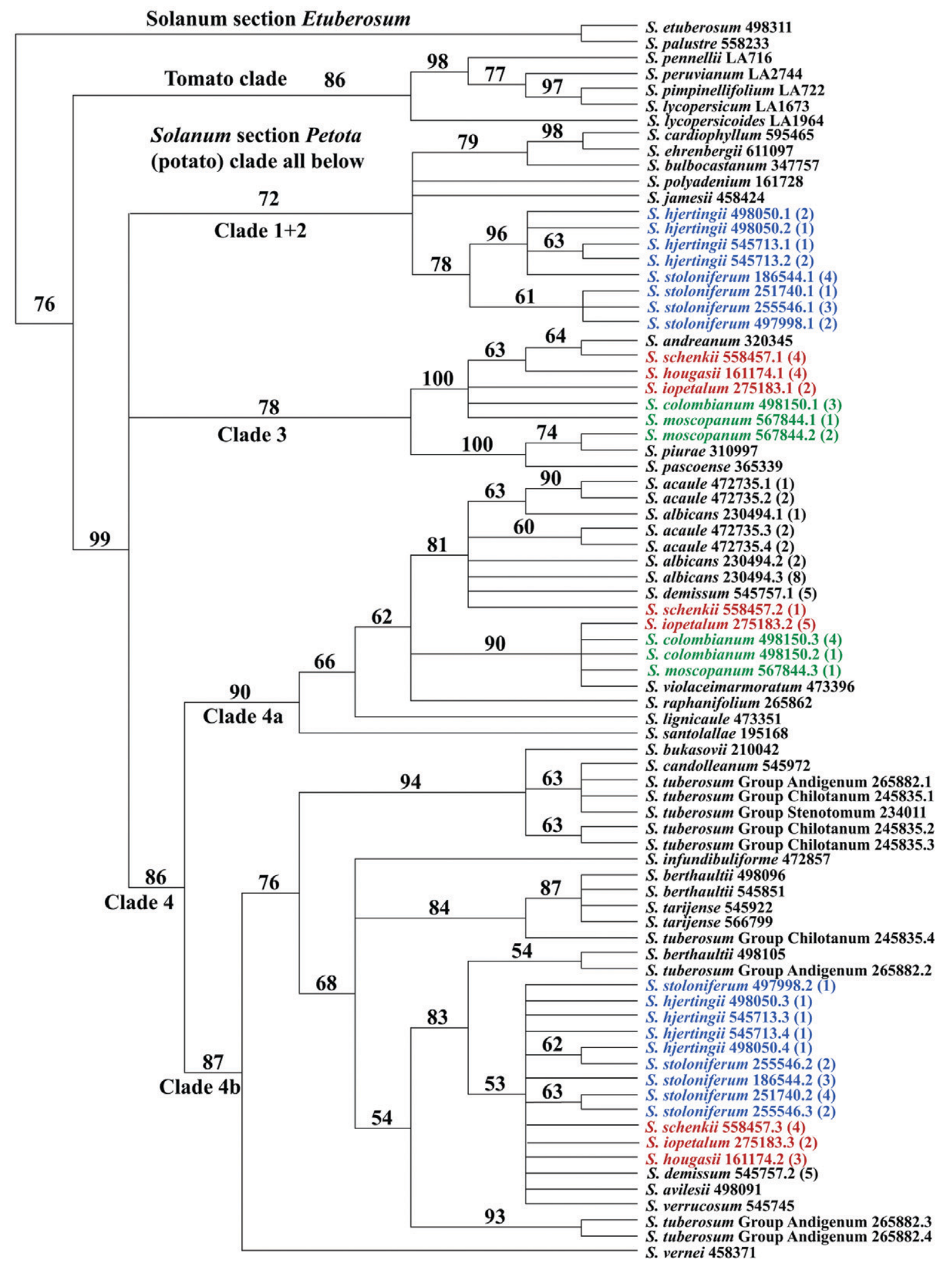

Figure 2. Strict consensus maximum parsimony tree from GBSSI sequence data of wild potatoes (Solanum sect. Petota) and outgroups in the tomato clade and Solanum sect. Etuberosum, with overlaid bootstrap values. Red accessions are members of the lopetala Group (all hexaploids), blue accessions of series Longipedicellata (all tetraploids), and green the tetraploid and hexaploid accessions of series Conicibaccata. Solanum acaule, S. albicans, S. demissum, and S. tuberosum Groups Andigenum and Chilotanum are also polyploid, while the remaining accessions are diploid. The numbering of the clades follows the convention of the plastid DNA results (Fig. 1). 
or its progenitor because this is the only A genome species in North and Central America.

The genomic contribution of species within series Piurana (clade 3) to series Conicibaccata and members of the Iopetala Group also is well supported by our GBSSI results but has not been suggested by previous authors. Matsubayashi (1991) designated polyploid members of series Conicibaccata as having $\mathrm{A}$ and $\mathrm{C}$ genomes and series Demissa as having $\mathrm{A}$ and $\mathrm{D}$ genomes; but the $\mathrm{C}$ and $\mathrm{D}$ genomes had no extant diploid species representatives. Our results identify these unknown C and D genomes as members of clade 3 , and corresponding to Matsubayashi's (1991) $\mathrm{A}^{\mathrm{P}}$ genome. As in the origin of the members of series Longipedicellata, the direction of the cross is well supported as a paternal contributor from members of clade 3 and a maternal origin from members of clade 4 , indicated by the plastid data.

All alleles of $S$. acaule and S. demissum fall entirely within clade 4 . All alleles of $S$. acaule cluster with some alleles of $S$. demissum and $S$. schenckii in clade $4 \mathrm{a}$, but $S$. demissum has alleles in clade $4 \mathrm{a}$ also that cluster with the alleles from species of the Iopetala Group and series Longipedicellata. Solanum acaule and S. albicans are putative allopolyploids but with only slight difference in their genomes, completely in accordance with findings of previous authors (Table 2), who also indicated only minor genomic differences in these species. This is in contrast to major differences in series Conicibaccata, series Longipedicellata, and the Iopetala Group.

Solanum tuberosum is an autotetraploid based on quadrivalent chromosome pairing. Its grouping in the same clade with S. bukasovii and S. candolleanum is expected on the basis of AFLP data of Spooner et al. (2005). There is no cultivar-group specific association of $S$. tuberosum Chilotanum Group with S. berthaultii (Hosaka, 2003).

In summary, our results provide the first molecular evidence of allopolyploidy in potato. We support prior ideas of allopolyploid origins for members of series Longipedicellata (as AABB genome from clades $1+2$ and clade 4 ), and show novel origins for members of series Conicibaccata and the Iopetala Group never suggested before (from clade 3 as $\mathrm{A}^{\mathrm{P}}$ or $\mathrm{P}$ genome and clade 4 as $\mathrm{A}$ genome). The latter results highlight the problems inherent in classic genome analysis and the need to reexamine long-held interpretations of genomic origins in other groups. Additional sequencing with other orthologous genes and using additional species is underway to provide better resolution to these allopolyploid origins.

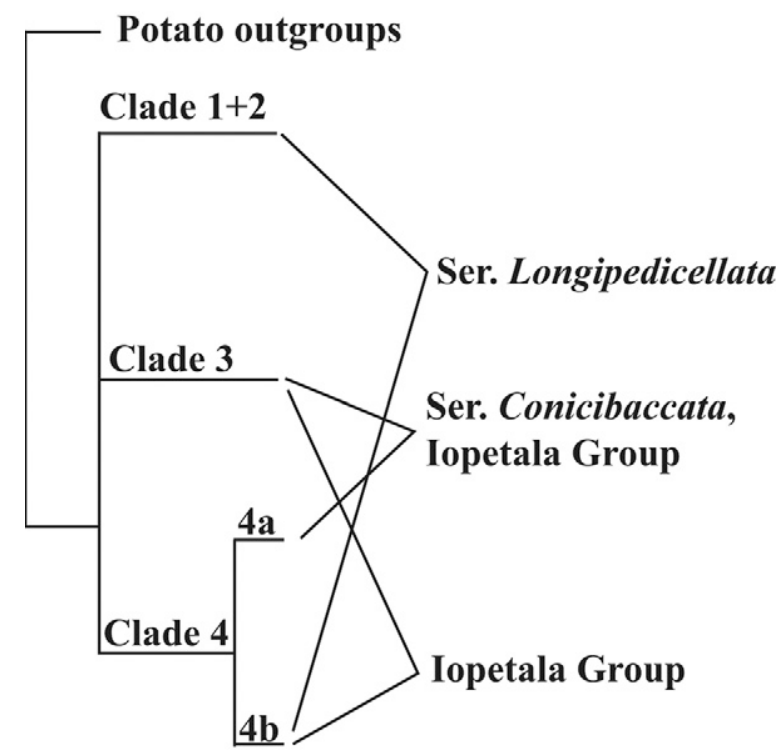

Figure 3. A summary of the cladistic relationships of the allopolyploid members of Solanum sect. Petota as shown in Fig. 2 using the series terminology of Hawkes (1990), except that the lopetala Group refers to members of Hawkes's series Demissa but excluding S. demissum (see text) (Table 2). Clade 1+2 combines species of these clades in the plastid tree of Fig. 1. Members of series Tuberosa and the Acaulia Group all fall within clade 4.

\section{Impact of This Study on Potato Breeding}

To use wild species effectively in potato breeding programs, it is important to consider both genomes and "endosperm balance number" (EBN). Entirely on the basis of empirical data, Solanum species have been assigned EBN numbers based on their ability to hybridize with each other (Hanneman, 1994). Barring other crossing barriers, successful hybridization is expected when male and female gametes have matching EBN values, regardless of ploidy. Ploidy (EBN) combinations in potato include $6 x(4 \mathrm{EBN}), 4 x$ (4EBN), $4 x(2 \mathrm{EBN}), 2 x(2 \mathrm{EBN})$, and $2 x(1 \mathrm{EBN})$.

Breeders use EBN values to determine whether interspecific crosses will succeed and to design strategies to access exotic germplasm by manipulating EBNs (Johnston and Hanneman, 1980). Endosperm balance numbers can be increased through somatic doubling (using colchicine or callus culture) or the production of $(2 n)$ gametes. Plants that express naturally occurring meiotic mutations produce $2 n$ gametes in which the chromosome number and EBN value of the parent plant is maintained, rather than reduced, during meiosis (Carputo et al., 2000; Peloquin et al., 1999). Some meiotic mutations result in the production of $2 n$ eggs (Stelly and Peloquin, 1986; Werner and Peloquin, 1990), while others produce $2 n$ pollen (Mok and Peloquin, 1975; Quinn et al., 1974). Endosperm balance numbers can also 
be reduced, through anther culture (Sonnino et al., 1989) or parthenogenesis (Hougas et al., 1958).

Series Longipedicellata (4x, 2EBN, AABB) species can be crossed to $2 x, 2 \mathrm{EBN}$, AA genome species because their endosperm balance numbers match despite different ploidy levels. The resulting hybrids are $3 x, 2 \mathrm{EBN}$ and AAB. Triploids are typically sterile because of their odd ploidy. A breeder has two options to produce fertile offspring. First, the triploids can be somatically doubled to produce $6 x, 4 \mathrm{EBN}, \mathrm{AAAABB}$ plants. When these hexaploids are crossed to $4 x, 4 \mathrm{EBN}$ AAAA cultivated potatoes, presumably the $B$ genome chromosomes will preferentially pair with each other, and limited recombination will occur between the A and B genomes.

Alternatively, a breeder can use a strategy in which chromosomes from the A genome must pair with those in the $\mathrm{B}$ genome. In this scheme, the triploids are screened for mutants that produce $2 n$ gametes. Homologous pairing is common in triploid hybrids between allopolyploids and diploids (Dvorak, 1983), so recombination between the A and $\mathrm{B}$ genomes is expected. This strategy was used by Adiwilaga and Brown (1991), who crossed 4x, 2EBN Longipedicellata species to $2 x, 2 \mathrm{EBN}$ plants. Several of the resulting triploids produced $2 n$ pollen $(3 x, 2 \mathrm{EBN})$ and were successfully crossed to $4 x, 4$ EBN cultivars (gametes $2 x, 2 \mathrm{EBN}$ ) to produce $5 x, 4 \mathrm{EBN}$ offspring.

The identification of the genomes that have contributed to allopolyploid species may provide a strategy for their use in bridging crosses. For example, S. bulbocastanum is a $2 x, 1 \mathrm{EBN}, \mathrm{BB}$ genome species that does not readily cross with the cultivated potato (Helgeson et al., 1998). Assuming no other crossing barriers, S. stoloniferum ( $4 x, 2 \mathrm{EBN}, \mathrm{AABB})$, for example, could be crossed to $2 n$ gamete-producing S. bulbocastanum $(2 x, 1 \mathrm{EBN}, \mathrm{BB})$ plants. The $2 x$, $1 \mathrm{EBN}, \mathrm{AB}$ S. stoloniferum gametes would unite with $2 x, 1$ EBN, BB gametes from S. bulbocastanum, producing $4 x, 2 \mathrm{EBN}, \mathrm{ABBB}$ hybrids. When these hybrids are crossed to a $2 x, 2 \mathrm{EBN}$, AA plant, chromosomes from the A genome would only have $B$ genome chromosomes as pairing partners, so recombination would be expected between the genomes. The resulting triploids could be selected for $2 n$ gametes $(3 x, 2 \mathrm{EBN})$ and crossed with tetraploids (gametes $2 x, 2 \mathrm{EBN}$ ) to produce $5 x, 4 \mathrm{EBN}$ hybrids. We are not aware of any reports of the use of the hexaploids in series Conicibaccata or the Iopetala Group in potato breeding programs, but our study can aid this process. We here show these to be allopolyploids of A genome and "clade 3." Similar to Matsubayashi (1991), we refer to species in clade 3 as $P$ genomes, not $\mathrm{C}$ or $\mathrm{D}$, as previously hypothesized (Table 2 ). We will assume that they are AAPPPP, as Matsubayashi
(1991) indicated for series Demissa hexaploids. The hexaploids carrying the $\mathrm{P}$ genome may provide a bridge to access species in series Piurana that have been difficult to cross to the cultivated potato, such as S. paucissectum (Villamon et al., 2005). A cross between a $6 x, 4 \mathrm{EBN}$, AAPPPP species (gametes $3 x$, $2 \mathrm{EBN}$ ) and a $2 n$ gamete-producing $2 x, 2 \mathrm{EBN}, \mathrm{PP}$ species in series Piurana (gametes $2 x, 2 \mathrm{EBN}$ ) would produce a $5 x, 4 \mathrm{EBN}$, APPPP hybrid. Recombination is expected to occur in the pentaploid hybrid as it is crossed to a $4 x, 4 \mathrm{EBN}$, AAAA cultivated potato plant. Crossing barriers other than EBN sometimes occur in interspecific Solanum crosses (Jansky, 2006), so EBN manipulations that work in theory may not work in practice.

In situ hybridization methods offer the potential to advance our understanding of genome evolution and polyploid formation (Gavrilenko, 2007). We are currently setting up the crosses outlined above and plan to use in situ hybridization to determine the scope and effects of preferential pairing in interspecific Solanum hybrids.

\section{Acknowledgments}

We thank the U.S. Potato Genebank, The C.M. Rick Tomato Genetic Resources Center, Gregory Anderson, Thomas Mione, and Richard Olmstead for providing seeds or germplasm samples for this study; Holly Ruess and Sarah Stephenson for technical assistance; and Jeffrey Doyle, Sara Hoot, and Randy Small for reviews. Names are necessary to report data. However, the USDA neither guarantees nor warrants the standard of the product, and the use of the name by the USDA implies no approval of the product to the exclusion of others that may also be suitable. This research was supported by the USDA and NSF DEB 0316614 to David Spooner entitled "PBI Solanum: A worldwide treatment (http://www.nhm.ac.uk/research-curation/ projects/solanaceaesource//).”

\section{References}

Adiwilaga, K.D., and C.R. Brown. 1991. Use of 2n pollen-producing triploid hybrids to introduce tetraploid Mexican wild species germ plasm to cultivated tetraploid potato gene pool. Theor. Appl. Genet. 81:645-662.

Carputo, D., A. Barone, and L. Frusciante. 2000. 2n gametes in the potato: Essential ingredients for breeding and germplasm transfer. Theor. Appl. Genet. 101:805-813.

Castillo, R., and D.M. Spooner. 1997. Phylogenetic relationships of wild potatoes, Solanum series Conicibaccata (sect. Petota). Syst. Bot. 22:45-83.

Clark, J.R., M. Robertson, and C.C. Ainsworth. 1991. Nucleotide sequence of a wheat (Triticum aestivum L.) cDNA clone encoding the waxy protein. Plant Mol. Biol. 16:1099-1101.

Cronn, R.C., R.L. Small, and J.F. Wendel. 1999. Duplicated genes evolve independently after polyploid formation in cotton. Proc. Natl. Acad. Sci. USA 96:14406-14411.

Culley, D., B. Dean, and C. Brown. 2002. Introgression of the low browning trait from the wild Mexican species Solanum hjertingii into cultivated potato (S. tuberosum L.). Euphytica 125:293-303.

DeJong, H., K.G. Proudfoot, and A.M. Murphy. 2001. The germplasm release of F87084, a fertile, adapted clone with multiple disease resistances. Am. J. Potato Res. 78:141-149. 
Doyle, J.J., and J.L. Doyle. 1999. Nuclear protein-coding genes in phylogeny reconstruction and homology assessment: Some examples from Leguminosae. p. 229-254. In R.J. Gornall (ed.) Molecular systematics and plant evolution. Taylor and Francis, London.

Doyle, J.J., J.L. Doyle, J.T. Rauscher, and A.D.H. Brown. 2004. Evolution of the perennial soybean polyploid complex (Glycine subgenus Glycine): A study of contrasts. Biol. J. Linn. Soc. 82:583-597.

Dry, I., A. Smith, A. Edwards, M. Bhattacharyya, P. Dunn, and C. Martin. 1992. Characterization of cDNAs encoding two isoforms of granule-bound starch synthase which show differential expression in developing storage organs of pea and potato. Plant J. 2:193-202.

Dvorak, J. 1983. Evidence for genetic suppression of heterogenetic chromosome pairing in polyploid species of Solanum, sect. Petota. Can. J. Genet. Cytol. 25:530-539.

Emshwiller, E., and J.J. Doyle. 2002. Origins of domestication and polyploidy in oca (Oxalis tuberosa: Oxalidaceae): 2. Chloroplast-expressed glutamine synthetase data. Am. J. Bot. 89:1042-1056.

Evans, R.C., L.A. Alice, C.S. Campbell, E.A. Kellogg, and T.A. Dickinson. 2000. The granule-bound starch synthase (GBSSI) gene in Rosaceae: Multiple loci and phylogenetic utility. Mol. Phylogenet. Evol. 17:388-400.

Ford, V.S., and L.D. Gottlieb. 2002. Single mutations silence PgiC2 genes in two very recent allotetratploid species of Clarkia. Evolution Int. J. Org. Evolution 56:699-707.

Gaut, B.S. 1998. Molecular clocks and nucleotide substitution rates in higher plants. Evol. Biol. 30:93-120.

Gavrilenko, T. 2007. Potato cytogenetics. p. 203-216. In D. Vruegdenhil (ed.) Potato biology and biotechnology: Advances and perspectives. Elsevier, Oxford, UK.

Ge, S., T. Sang, B. Lu, and D. Hong. 1999. Phylogeny of rice genomes with emphasis on origins of allotetraploid species. Proc. Natl. Acad. Sci. USA 96:14400-14405.

Hanneman, R.E., Jr. 1994. Assignment of endosperm balance numbers to the tuber-bearing Solanums and their close non-tuberbearing relatives. Euphytica 74:19-25.

Hawkes, J.G. 1958. Kartoffel: I. Taxonomy, cytology and crossability. p. 1-43. In H. Kappert and W. Rudorf (ed.) Handbuch Pflanzenzüchtung, 2nd ed. Vol. 3. Paul Parey, Berlin.

Hawkes, J.G. 1990. The potato: Evolution, biodiversity, and genetic resources. Belhaven Press, Washington, DC.

Helgeson, J.P., J.D. Pohlman, S. Austin, G.T. Haberlach, S.M. Wielgus, D. Ronis, L. Zambolim, P. Tooley, J.M. McGrath, R.V. James, and W.R. Stevenson. 1998. Somatic hybrids between Solanum bulbocastanum and potato: A new source of resistance to late blight. Theor. Appl. Genet. 96:738-742.

Hoot, S.B., N.S. Napier, and W.C. Taylor. 2004. Revealing unknown or extinct lineages within Isoëtes (Isoëtaceae) using DNA sequences from hybrids. Am. J. Bot. 91:899-904.

Hosaka, K. 2003. T-type chloroplast DNA in Solanum tuberosum L. ssp. tuberosum was conferred from some populations of $S$. tarijense Hawkes. Am. J. Potato Res. 80:21-32.

Hougas, R.W., S.J. Peloquin, and R.W. Ross. 1958. Haploids of the common potato. Heredity 49:103-106.

Ingram, A.L., and J.J. Doyle. 2003. The origin and evolution of Eragrostis tef (Poaceae) and related polyploids: Evidence from nuclear waxy and plastid rps16. Am. J. Bot. 90:116-122.

Irikura, Y. 1976. Cytogenetic studies on the haploid plants of tuberbearing Solanum species: II. Cytogenetic investigations on haploid plants and interspecific hybrids by utilizing haploidy. (In Japanese, with English summary). Res. Bull. Hokkaido Natl. Agric. Res. Stn. 115:1-80.

Jansky, S. 2000. Breeding for disease resistance in potato. Plant Breed. Rev. 19:69-155.
Jansky, S. 2006. Overcoming hybridization barriers in potato. Plant Breed. 125:1-12.

Johnston, S.A., and R.E. Hanneman, Jr. 1980. Support of the endosperm balance number hypothesis utilizing some tuberbearing Solanum species. Am. Potato J. 57:7-14.

Kardolus, J.P. 1999. Morphological variation within series Acaulia Juz. (Solanum sect. Petota). p. 257-274. In M. Nee et al. (ed.) Solanaceae IV: Advances in biology and utilization. Royal Botanic Gardens, Kew, UK.

Kardolus, J.P., H.J. van Eck, and R.G. van den Berg. 1998. The potential of AFLPs in biosystematics: A first application in Solanum taxonomy (Solanaceae). Plant Syst. Evol. 210:87-103.

Kihara, H. 1919. Ueber cytologische Studien bei einigen Getreidearten: 1. Spezies-Bastarde des Weizens und WeizenroggenBastard. Bot. Mag. 32:17-38.

Marks, G.E. 1955. Cytogenetic studies in tuberous Solanum species: I. Genomic differentiation in the Group Demissa. J. Genet. 53:262-269.

Mason-Gamer, R.J. 2001. Origin of North American Elymus (Poaceae:Triticeae) allotetraploids based on granule-bound starch synthase gene sequences. Syst. Bot. 26:757-768.

Mason-Gamer, R.J. 2004. Reticulate evolution, introgression, and intertribal gene capture in an allohexaploid grass. Syst. Biol. 53:25-37.

Mason-Gamer, R.J., and E.A. Kellogg. 1996. Potential utility of the nuclear gene waxy for plant phylogenetic analysis. Am. J. Bot. 83:178 (supplement).

Matsubayashi, M. 1991. Phylogenetic relationships in the potato and its related species. p. 93-118. In T. Tsuchiya and P.K. Gupta (ed.) Chromosome engineering in plants: Genetics, breeding, evolution, part B. Elsevier Science BV, Amsterdam.

Mok, D.W.S., and S.J. Peloquin. 1975. Three mechanisms of $2 \mathrm{n}$ pollen formation in diploid potatoes. Can. J. Genet. Cytol. 17:217-225.

Nakagawa, K., and K. Hosaka. 2002. Species relationships between a wild tetraploid potato species, Solanum acaule Bitter, and its related species as revealed by RFLPs of chloroplast and nuclear DNA. Am. J. Potato Res. 79:85-98.

Peloquin, S.J., L.S. Boiteux, and D. Carputo. 1999. Meiotic mutants in potato: Valuable variants. Genetics 153:1493-1499.

Peralta, I.E., and D.M. Spooner. 2001. GBSSI gene phylogeny of wild tomatoes (Solanum L. section Lycopersicon [Mill.] Wettst. subsection Lycopersicon). Am. J. Bot. 88:1888-1902.

Plaisted, R.L., and R.W. Hoopes. 1989. The past record and future prospects for the use of exotic potato germplasm. Am. Potato J. 66:603-627.

Quinn, A.A., D.W.S. Mok, and S.J. Peloquin. 1974. Distribution and significance of diplandroids among the diploid Solanums. Am. Potato J. 51:16-21.

Ramanna, M.S., and J.G.T. Hermsen. 1979. Genome relationships in tuber-bearing Solanums. p. 647-654. In J.G. Hawkes et al. (ed.) The biology and taxonomy of the Solanaceae. Linnean Soc. of London Ser. 7. Academic Press, London.

Rodríguez, A., and D.M. Spooner. 1997. Chloroplast DNA analysis of Solanum bulbocastanum and S. cardiophyllum, and evidence for the distinctiveness of S. cardiophyllum subsp. ehrenbergii (sect. Petota). Syst. Bot. 22:31-43.

Ross, H. 1986. Potato breeding: Problems and perspectives. Paul Parey, Berlin.

Sang, T. 2002. Utility of low-copy nuclear gene sequences in plant phylogenetics. Crit. Rev. Biochem. Mol. Biol. 37:121-147.

Sang, T., and D. Zhang. 1999. Reconstructing hybrid speciation using sequences of low copy nuclear genes: Hybrid origins of five Paeonia species based on Adh gene phylogenies. Syst. Bot. 24:148-163.

Senchina, D.S., I. Alvarez, R.C. Cronn, B. Liu, J. Rong, R.D. Noyes, A.H. Paterson, R.A. Wing, T.A. Wilkins, and J.F. Wendel. 
2003. Rate variation among nuclear genes and the age of polyploidy in Gossypium. Mol. Biol. Evol. 20:633-643.

Shure, M., S. Wessler, and N. Fedoroff. 1983. Molecular identification and isolation of the Waxy locus in maize. Cell 35:225-233.

Simmons, M.P., and H. Ochoterena. 2000. Gaps as characters in sequence-based phylogenetic analyses. Syst. Biol. 49:369-381.

Small, R.L., R.C. Cronn, and J.F. Wendel. 2004. Use of nuclear genes for phylogeny reconstruction in plants. Aust. Syst. Bot. 17:145-170.

Sonnino, A., S. Tanaka, M. Iwanaga, and L. Schilde-Rentscher. 1989. Genetic control of embryo formation in anther culture of diploid potatoes. Plant Cell Rep. 8:105-107.

Spooner, D.M., G.J. Anderson, and R.K. Jansen. 1993. Chloroplast DNA evidence for the interrelationships of tomatoes, potatoes, and pepinos (Solanaceae). Am. J. Bot. 80:676-688.

Spooner, D.M., and R. Castillo. 1997. Reexamination of series relationships of South American wild potatoes (Solanaceae: Solanum sect. Petota): Evidence from chloroplast DNA restriction site variation. Am. J. Bot. 84:671-685.

Spooner, D.M., D. Fajardo, and G.J. Bryan. 2007a. Species limits of Solanum berthaultii Hawkes and S. tarijense Hawkes and the implications for species boundaries in Solanum sect. Petota. Taxon 56:987-999.

Spooner, D.M., K. McLean, G. Ramsay, R. Waugh, and G.J. Bryan. 2005. A single domestication for potato based on multilocus AFLP genotyping. Proc. Natl. Acad. Sci. USA 102:14694-14699.

Spooner, D.M., J. Núñez, G. Trujillo, M. del Rosario Herrera, F. Guzmán, and M. Ghislain. 2007b. Extensive simple sequence repeat genotyping of potato landraces supports a major reevaluation of their gene pool structure and classification. Proc. Natl. Acad. Sci. USA 104:19398-19403.

Spooner, D.M., and A. Salas. 2006. Structure, biosystematics, and genetic resources. p. 1-39. In J. Gopal and S.M. Paul Khurana (ed.) Handbook of potato production, improvement, and postharvest management. Haworth Press, Binghampton, NY.

Spooner, D.M., and K.J. Sytsma. 1992. Reexamination of series relationships of Mexican and Central American wild potatoes (Solanum sect. Petota): Evidence from chloroplast DNA restriction site variation. Syst. Bot. 17:432-448.

Spooner, D.M., K.J. Sytsma, and E. Conti. 1991. Chloroplast DNA evidence for genome differentiation in wild potatoes (Solanum sect. Petota: Solanaceae). Am. J. Bot. 78:1354-1366.

Spooner, D.M., R.G. van den Berg, and J.B. Bamberg. 1995. Examination of species boundaries of Solanum series Demissa and potentially related species in series Acaulia and series Tuberosa (sect. Petota). Syst. Bot. 20:295-314.

Spooner, D.M., R.G. van den Berg, A. Rodríguez, J. Bamberg, R.J. Hijmans, and S.I. Lara-Cabrera. 2004. Wild potatoes (Solanum section Petota) of North and Central America. Syst. Bot. Monogr. 68:1-209.
Staden, R. 1996. The Staden sequence analysis package. Mol. Biotechnol. 5:233-241.

Stelly, D.M., and S.J. Peloquin. 1986. Formation of 2n megagametophytes in diploid tuber-bearing Solanums. Am. J. Bot. 73:1351-1363.

Swofford, D.L. 2002. PAUP*: Phylogenetic analysis using parsimony (*and other methods), version 4. Sinauer Assoc., Sunderland, MA.

Templeton, A.R. 1983. Phylogenetic inference from restriction endonuclease cleavage site maps with particular reference to the evolution of humans and the apes. Evolution Int. J. Org. Evolution 37:221-244.

Thompson, J.D., T.J. Gibson, F. Plewniak, F. Jeanmougin, and D.G. Higgins. 1997. The ClustalX windows interface: Flexible strategies for multiple sequence alignment aided by quality analysis tools. Nucleic Acids Res. 24:4876-4882.

van der Leij, F.R., R.G.F. Visser, A.S. Ponstein, E. Jacobsen, and W.J. Feenstra. 1991. Sequence of the structural gene for granulebound starch synthase of potato (Solanum tuberosum L.) and evidence for a single point deletion in the amf allele. Mol. Gen. Genet. 228:240-248.

Vanichanon, A., N.K. Blake, J.D. Sherman, and L.E. Talbert. 2003. Multiple origins of allopolyploid Aegilops triuncialis. Theor. Appl. Genet. 106:804-810.

Vega, S.E., J.P. Palta, and J.B. Bamberg. 2000. Variability in the rate of cold acclimation and deacclimation among tuber-bearing Solanum (potato) species. J. Am. Soc. Hortic. Sci. 125:205-211.

Villamon, F.G., D.M. Spooner, M. Orrillo, E. Mihovilovich, W. Pérez, and M. Bonierbale. 2005. Late blight resistance linkages in a novel cross of the wild potato species Solanum paucissectum (series Piurana). Theor. Appl. Genet. 111:1201-1214.

Wang, S.J., K.W. Yeh, and C.Y. Tsai. 1999. Molecular characterization and expression of starch granule-bound starch synthase in the sink and source tissues of sweet potato. Physiol. Plant. 106:253-261.

Wendel, J.F., and J.J. Doyle. 1998. Phylogenetic incongruence: Window into genome history and molecular evolution. p. 265-296. In D.E. Soltis et al. (ed.) Molecular systematics of plants II: DNA sequencing. Kluwer Academic, Boston, MA.

Werner, J.E., and S.J. Peloquin. 1990. Inheritance and two mechanisms of $2 \mathrm{n}$ egg formation in 2x potatoes. J. Hered. 81:371-374.

Wolfe, K.H., W.-H. Li, and P.M. Sharp. 1987. Rates of nucleotide substitution vary greatly among plant mitochondrial, chloroplast, and nuclear DNAs. Proc. Natl. Acad. Sci. USA 84:9054-9058.

Wu, F., L.A. Mueller, D. Crouzillat, V. Pétiard, and S.D. Tanksley. 2006. Combining bioinformatics and phylogenetics to identify large sets of single-copy orthologous genes (COSII) for comparative, evolutionary and systematic studies: A test case in the euasterid plant clade. Genetics 174:1407-1420. 